\title{
KAWIN SADARAH DALAM KABA SI BUYUANG KARUIK; TINJAUAN SOSIOLOGIS
}

\section{INCEST IN KABA SI BUYUANG KARUIK: SOCIOLOGICAL REVIEWS}

\author{
Fitria dewi \\ Balai Bahasa Sumatra Barat \\ dewi_kinari@yahoo.com
}

\begin{abstract}
ABSTRAK
Perkawinan sedarah adalah perkawinan terlarang karena melanggar norma agama dan adat. Penelitian ini bertujuan untuk mendeskripsikan faktor-faktor penyebab terjadinya perkawinan sedarah dan akibat perkawinan sedarah itu dalam Kaba Si Buyuang Karuik. Penelitian ini menggunakan metode simak dan teknik catat dalam mengumpulkan data, selanjutnya data dianalisis melalui pendekatan sosiologi sastra dengan teori refleksi dan metoe analisis isi. Berdasarkan hasil penelitian ditemukan lima faktor penyebab terjadinya kawin sedarah tersebut, yaitu kemiskinan, kesedihan, kriminalitas, cinta, dan ketidaktahuan. Hasil penelitian juga menunjukkan bahwa perkawinan sedarah itu telah menyebabkan rasa malu yang tak terhindarkan, rasa sedih yang tak tertanggungkan, dan perceraian yang tak terhindarkan.
\end{abstract}

Kata kunci: kaba, perkawinan sedarah, sosiologi sastra

\begin{abstract}
Inbreeding is a prohibited marriage because it violates religious and customary norms. This study aims to describe the factors causing the occurrence of inbreeding and the consequences of inbreeding in Kaba Si Buyuang Karuik. This study uses the method of listening and note-taking technique in collecting data, then the data are analyzed through a sociological approach with reflection theory and the content analysis methods. Based on the results of the study, there are five factors causing the incest, namely poverty, sadness, crime, love, and ignorance. The results also show that inbreeding has caused inevitable shame, unbearable sadness, and inevitable divorce.
\end{abstract}

Keywords: kaba, incest, literary sociology

\section{PENDAHULUAN}

Istilah kawin sadarah atau perkawinan sedarah dapat didefinsikan sebagai perkawinan yang terjadi antara laki-laki dan perempuan yang bertali darah. Perkawinan sedarah ini dipandang tabu dan ilegal karena dianggap menyalahi norma dan melanggar undang-undang perkawinan. Pasal 1 Undang-Undang Perkawinan menetapkan definisi perkawinan sebagai ikatan lahir batin antara seorang pria dengan seorang wanita sebagai suami istri dengan tujuan membentuk keluarga (rumah tangga) yang bahagia dan kekal berdasarkan Ketuhanan Yang Maha Esa. Berdasarkan definisi itu, dapat diuraikan bahwa dalam sebuah perkawinan terdapat tiga unsur utama, yaitu, perkawinan merupakan persekutuan hidup antara seorang laki-laki dan seorang perempuan, perkawinan harus 
dilakukan berdasarkan peraturan perundang-undangan yang berlaku di Indonesia, dan perkawinan mempunyai hubungan erat dengan agama.

Dalam hukum Islam, perkawinan diartikan sebagai suatu akad atau perikatan untuk menghalalkan hubungan kelamin antara lelaki dan perempuan dalam rangka mewujudkan kebahagiaan hidup keluarga yang diliputi rasa ketentraman serta kasih sayang dengan cara yang diridhoi Allah (Soemiyati, 1986:47). Berdasarkan pengertian ini juga dapat diuraikan unsur-unsur utama dalam perkawinan, yaitu perkawinan merupakan perikatan anara laki-laki dan perempuan, perkawinan memiliki tujuan untuk mewujudkan keluarga yang bahagia, dan perkawinan harus dilaksanakan dengan cara yang diridhai Allah.

Apabila definisi perkawinan menurut pasal 1 UU Perkawinan dibandingkan dengan pengertian perkawinan menurut hukum islam, maka tidak ditemukan perbedaan yang mendasar. Keduanya sama-sama menyatakan bahwa perkawinan terjadi antara laki-laki dan perempuan, menurut hukum yang berlaku, dan mendasarkan pada syariat agama. Dapat disimpulkan bahwa perkawinan pada dasarnya adalah suatu perjanjian untuk hidup bersama antara seorang laki-laki dengan seorang perempuan sesuai peraturan yang berlaku dengan tujuan untuk membentuk rumah tangga berdasarkan ketuhanan yang maha esa. Hal ini sejalan dengan pendapat Djais yang menyatakan bahwa hakikat perkawinan adalah persatuan antara laki-laki dan perempuan di dalam hokum keluarga dengan pertalian yang say antara seorang laki-laki dengan seorang perempuan untuk waktu yang lama (2006:4).

Pada umumnya, perkawinan dianggap sebagai sesuatu yang suci dan karenanya setiap agama selalu menghubungkan norma-norma perkawinan dengan norma-norma agama. Selain norma agama, perkawinan juga berkaitan erat dengan norma adat. Kata 'norma' didefinisikan sebagai aturan atau ketentuan yang mengikat warga kelompok dalam masyarakat, dipakai sebagai panduan, tatanan, dan pengendali tingkah laku yang sesuai dan berterima. Sehingga norma adat dapat dipahami sebagai aturan atau ketentuan yang lazim diturut atau dilakukan dalam masyarakat sejak dahulu sebagai panduan yang sesuai dan berterima.

Dalam norma agama islam, diterangkan dua hal penting yang harus diperhatikan ketika memilih jodoh, yakni memilih pasangan berdasarkan keimanan dan memastikan garis nasab atau mahramnya (https://dalamislam.com/hukum-islam/pernikahan/syarat-pernikahan-dalam-

islam). Sedangkan perkawinan yang ideal menurut orang Minangkabau adalah perkawinan awak samo awak (sesama kita, maksudnya perkawinan yang dilangsung antara lelaki suku Minangkabau dengan perempuan sesama suku bangsa Minangkabau, atau sebaliknya. http://erialfiansyah94.blogspot.com/2015/04/kebudayaan-perkawinan-

minangkabau.html. Berdasarkan definisi tersebut dapat disimpulkan bahwa dalam pandangan adat Minangkabau juga diperhatikan agama dan keturunan. Hal itu tersirat dari aturan perkawinan antara lelaki suku minang dengan perempuan suku minang. Apabila seseorang disebut bersuku Minang maka dapat dipastikan ia beragama islam, dan bersuku Minang juga menegaskan bahwa garis keturunannya sudah jelas. 
Perkawinan yang tidak menyalahi norma hukum, norma agama, dan norma adat dapat dikatakan sebagai perkawinan yang ideal. Maka perkawinan yang menyalahi salah satu norma tersebut dapat dikatakan sebagai perkawinan yang tidak ideal. Perkawinan yang tidak ideal, yang melanggar aturan yang paling krusial, disebut juga dengan perkawinan terlarang. Dalam adat Minangkabau, perkawinan terlarang sering disebut kawin bapantang "perkawinan berpantang", yaitu perkawinan yang tidak dapat dilakukan. Jika ada yang melakukan 'perkawinan berpantang" maka akan dikenakan sanksi hukuman. Perkawinan berpantang menurut adat Minangkabau, salah satunya adalah perkawinan sedarah.

Perkawinan sedarah, selain melanggar adat juga tidak sesuai dengan syariat Islam seperti mengawini ibu, ayah, saudara, anak, saudara seibu dan sebapak, saudara ibu dan bapak, saudara kandung, istri atau suami dan anak saudara lakilaki ayah (http://erialfiansyah94.blogspot.com/2015/04/kebudayaan-perkawinanminangkabau.html). Berdasarkan definisi tersebut dapat disimpulkan bahwa perkawinan sedarah adalah perkawinan yang melanggar norma agama, norma hukum, dan norma adat.

Kasus perkawinan sedarah yang baru saja terungkap adalah perkawinan antara adik dan kakak kandung di Desa Lamunre Tengah, Kecamatan Belopa Utara, Kabupaten Luwu, Sulawesi Selatan. Ketika kasus tersebut terungkap, warga yang mengetahuinya sangat marah sehingga mengusir keluarga pelaku. Pihak yang berwajib akhirnya turun tangan menangani kasus tersebut (tribunnews.com, Minggu 28 Juli 2019). Kasus perkawinan sedarah lainnya juga ditemukan di Kabupaten Bulukumba, Sulawesi Selatan. Kasus tersebut juga ditangani pihak berwenang. Keluarga pelaku mengaku sangat malu dan tidak mau menerima anak-anak mereka yang dinilai salah langkah tersebut (liputan6.com, 3 Juli 2019).

Menyimak kedua contoh kasus di atas, perkawinan sedarah sama-sama menuai sanksi hukum dan sanksi sosial. Hal itu hendaknya dapat dijadikan pelajaran bagi siapapun yang akan menikah. Selain dalam kehidupan nyata, kasus perkawinan sedarah juga ditemukan dalam karya sastra Minangkabau, yakni dalam kaba berjudul "Sibuyung Karuik".

Secara etimologis kaba berasal dari bahasa Arab khabar (tunggal), akhbaruun (jamak). Khabar berarti berita, cerita, atau pesan. Kaba dapat pula disamakan dengan hikayat dalam sastra Melayu (sastra Indonesia lama). Kaba merupakan percampuran berbagai konsep universal yang sejalan dengan tradisi masyarakat Minang (Abdullah, 2009:118). Kaba adalah salah satu jenis karya sastra Minangkabau yang utama dan paling populer dibandingkan pantun, pepatah-petitih, dan mantra (Djamaris, 2004:1).

Berdasarkan karakteristiknya, kaba dapat dibagi dalam dua kelompok, yaitu kaba klasik atau kaba lama dan kaba modern atau kaba baru. Ciri-ciri kaba klasik adalah 1) ceritanya mengenai perebutan kekuasaan antara dua kelompok dan 2) ceritanya dianggap berlaku pada masa lampau yang jauh, tentang anak raja dengan kekuatan supranatural. Kaba modern memiliki ciri-ciri 1) bercerita tentang anak muda yang pada mulanya miskin, tetapi karena usahanya dalam perdagangan, ia berubah menjadi seorang yang kaya yang dapat menyumbangkan kekayaannya bagi kepentingan keluarga matrilinialnya hingga ia berbeda dari 
mamaknya, 2) ceritanya dianggap berlaku pada masa lampau yang dekat, akhir abad ke-19 yang bercerita tentang manusia biasa tanpa kekuatan supranatural (Djamaris, 2004:7-8).

Kaba Si Buyuang Karuik (KSBK) tergolong kaba modern, karena kaba tersebut bercerita tentang anak muda yang pada mulanya miskin tetapi karena usahanya dalam perdagangan, ia menjadi seorang yang kaya. KBSK dibukukan oleh Syamsuddin St. Radjo Endah. Kaba ini pertama kali diterbitkan oleh CV Pustaka Indonesia pada tahun 1960. Selanjutnya diterbitkan ulang oleh Penerbit Buku Alam Minangkabau "Kristal Multimedia" pada tahun 2004. Kaba ini mengantarkan kisah dari ranah Pariaman, menceritakan dua orang kakak beradik yang pergi meninggalkan kampung halaman karena kemiskinan. Semenjak meninggalkan kampung halamannya, penderitaan demi penderitaan dijalani Si Buyuang Karuik dan adik perempuannya dengan penuh kesabaran. Sampai mereka dipisahkan oleh nasib masing-masing. Dan nasib jugalah yang mempertemukan mereka kembali sebagai suami istri.

Secara umum tulisan ini bermaksud mengkaji pesan-pesan moral yang tersirat dari kisah perkawinan sedarah dalam KBSK. Secara khusus, penelitian ini membahas beberapa masalah, yakni 1) Apakah faktor penyebab terjadinya perkawinan sedarah dalam KBSK? 2) Bagaimanakah dampak perkawinan sedarah dalam KBSK? Dengan demikian, maka tujuan penelitian ini adalah untuk: 1) mendeskripsikan faktor-faktor penyebab terjadinya perkawinan sedarah dalam KBSK, dan 2) mendeskripsikan dampak yang timbulkan akibat terjadinya perkawinan sedarah dalam KBSK.

Hadirnya sebuah penelitian ilmiah pada hakikatnya tidak terlepas dari penelitian-penelitian lainnya. Penelitian tersebut merupakan pelengkap dari rantai panjang penelitian yang telah ada dan penyambung jalan bagi penelitian selanjutnya. Penelitian ini merujuk pada beberapa penelitian bertema perkawinan yang pernah dilakukan oleh peneliti sebelumnya.

Penelitian pertama dilakukan oleh Karini (2007) yang dipaparkan dalam tesis berjudul "Perkawinan Campur dalam Novel Rojak Karya Fira Basuki". Dalam penelitiannya penulis membahas keuntungan dan kerugian kehidupan perkawinan campur bagi tokoh utama dalam novel Rojak. Selain itu penulis juga mengungkapkan hubungan kehidupan perkawinan campur dalam novel Rojak karya Fira Basuki dengan realitas kehidupan masyarakat pada masa sekarang. Penulis menggunakan pendekatan sosiologi sastra dan metode analisis deskriptif untuk mendeskripsikan permasalahan-permasalahan yang ada dalam teks karya sastra tersebut. Hasil penelitian ini menunjukkan keuntungan perkawinan campur adalah a) Terjadi perpaduan budaya yang bisa menciptakan kebudayaan baru, b) Pengetahuan budaya semakin beragam, c) Penguasaan bahasa lebih beragam. Adapun kerugian adalah semua konflik yang tidak bisa diatasi. Konflik-konflik itu adalah a) Konflik Suami-Istri, b) Konflik Budaya. Meliputi bahasa dan makanan, c) Konflik mertua-Pembantu. Hubungan novel Rojak dengan kehidupan perkawinan pada masa sekarang berkaitan sangat erat. Pengarang benar-benar mengambil ide cerita dari peristiwa yang terjadi di sekitarnya, mengenai perkawinan campur. 
Penelitian kedua tentang perkawinan adalah penelitian yang dilakukan oleh Saputra (2018) berjudul "Perkawinan daam Novel Ketika Cinta Bertasbih Perspektif Hukum Perkawinan Islam di Indonesia". Melalui penelitian itu dikaji struktur wacana tulisan Habiburrahman, konteks sosialnya, dan kognisi sosialnya. Selain itu dibahas pula analisis kesesuaian wacana perkawinan seperti perjanjian perkawinan dan pembatalan perkawinan yang ada dalam novel "Ketika Cinta Bertasbih" dengan hukum Islam yang ada di Indonesia. Metode yang digunakan dalam penelitian ini adalah analisis wacana dengan pendekatan kualitatif. Hasil yang didapat dari analisis isu-isu perkawinan yang dibahas dalam penelitian ini adalah perjanjian perkawinan yang sesuai dengan hukum perkawinan Islam di Indonesia dan jalan perceraian yang seharusnya tidak ditempuh melainkan pembatalan perkawinan. Novel ini mempunyai muatan pesan-pesan kebaikan yang membangun jiwa.

Penelitian-penelitian itu memiliki relevansi dengan penelitian ini. Persamaan yang paling mendasar adalah sama-sama menganalisis tentang perkawinan dalam karya sastra. Sepanjang penelusuran kepustakaan yang penulis lakukan, dapat dikatakan bahwa penelitian mengenai perkawinan sedarah dalam KBSK belum pernah dilakukan.

\section{METODE PENELITIAN}

Penelitian mengenai faktor penyebab terjadinya perkawinan sedarah dalam KSBK dan dampak yang ditimbulkan akibat perkawinan sedarah tersebut dikaji dengan pendekatan sosiologi sastra. Menurut Sapardi, pendekatan sosiologi sastra mempunyai perhatian terhadap sastra sebagai institusi sosial yang diciptakan oleh sastrawan sebagai anggota masyarakat (Damono, 1978). Berdasarkan pengertian itu, Sastra dipahami sebagai cerminan dari masyarakat, maksudnya, melalui karya sastra, pengarang mengungkapkan problema kehidupan yang terjadi di masyarakaat. Sehingga dapat dikatakan bahwa karya sastra menerima pengaruh dari masyarakat dan sekaligus mampu memberi pengaruh terhadap masyarakat. Hal itu sejalan dengan pendapat Pradopo yang mengatakan bahwa pendekatan sosiologi sastra berorientasi mimetik, karena memandang karya sastra sebagai cerminan masyarakat, yang perhatiannya berpusat pada struktur kemasyarakatan dalam karya sastra (Pradopo: 1995, v). Berkaitan dengan itu, maka pendekatan sosiologi sastra digunakan untuk memahami problema kehidupan yang dikisahkan dalam KBSK sebagai cerminan kehidupan masyarakat Minangkabau pada masa itu.

Perspektif klasik sosiologi sastra adalah meletakkan sastra sebagai informasi tentang masyarakat. Pada level tertentu, sastra bisa dilihat sebagai sumber inspirasi tindakan sosial. Hal itu didasarkan pada prinsip bahwa karya sastra merupakan refleksi masyarakat pada zaman karya itu ditulis (Damono, 1978:19). Teori yang mengatakan bahwa sastra dapat dibaca sebagai informasi tentang nilai dan perilaku sosial disebut teori refleksi (sosiologi.com). Berdasarkan pemahaman itu, maka penelitian tentang faktor penyebab terjadinya perkawinan sedarah dalam KSBK dan dampak yang ditimbulkan akibat perkawinan sedarah tersebut dikaji dengan menggunakan teori refleksi. 
Penelitian ini bersifat deskriptif karena bertujuan untuk memaparkan dan menjelaskan faktor-faktor penyebab terjadinya perkawinan sedarah dan dampak yang ditimbulkan akibat perkawinan sedarah itu. Selain itu, Penelitian ini juga bersifat kualitatif karena data penelitian tidak berhubungan dengan angka-angka, tetapi berupa kata, frasa, dan kalimat. Arikunto (1998:193) menyebutkan bahwa penelitian kualitatif merupakan penelitian deskriptif karena penelitian ini berusaha menggambarkan data dengan kata-kata atau kalimat untuk memperoleh suatu kesimpulan. Penelitian ini dilakukan dengan mengumpulkan data berupa data deskriptif tentang faktor-faktor penyebab terjadinya perkawinan sedarah dan dampak perkawinan itu dari kisah KSBK. Hal itu didasarkan pada pemahaman bahwa penelitian kualitatif adalah salah satu prosedur penelitian yang menghasilkan data deskriptif berupa ucapan atau tulisan dan perilaku orang-orang yang diamati (Bodgan dan Taylor, 1992).

Penelitian ini dapat digolongkan pada penelitian kepustakaan karena peneliti mengumpulkan data dari sumber tertulis berbentuk buku (naskah kaba yang sudah dibukukan). Data penelitian ini adalah petikan isi kaba yang di dalamnya terdapat faktor penyebab terjadinya perkawinan sedarah dan akibat perkawinan sedarah itu. Objek penelitian ini adalah faktor-faktor yang menyebabkan terjadinya perkawinan sedarah itu dan akibat yang ditemukan dalam naskah KSBK.

Metode adalah cara yang harus dilaksanakan, sedangkan teknik adalah cara melaksanakan metode. Sebagai cara, identitas teknik ditentukan oleh alat yang dipakai (Sudaryanto, 2015:9). Untuk menyediakan data mengenai faktor-faktor penyebab terjadinya perkawinan sedarah dan akibat yang ditimbulkannya, peneliti menggunakan metode simak dan teknik catat. Menurut Sudaryanto (2015:203), metode simak dilakukan dengan menyimak isi teks. Sumber data penelitian ini adalah teks tertulis berupa naskah KSBK. Oleh karena itu, penyimakan yang dimaksud dalam proses penyediaan data adalah menyimak isi cerita yang dikisahkan dalam naskah KSBK.

Salah satu metode yang digunakan dalam upaya menemukan kaidah dalam tahap analisis data adalah metode analisis isi. Analisis isi merupakan suatu teknik penelitian untuk menguraikan isi komunikasi yang jelas secara objektif, sistematis, dan kuantitatif (Berelson dalam Ibrahim, 2009: 97). Selain itu, analisis isi merupakan teknik penelitian yang ditujukan untuk membuat kesimpulan dengan cara mengidentifikasi karakteristik tertentu pada pesan-pesan secara sistematis dan objektif (Holsti dalam Ibrahim, 2009: 97).

\section{PEMBAHASAN}

\section{Ringkasan Cerita Kaba Si Buyuang Karuik}

Siti Jamilah dan Bagindo Baha memiliki dua orang anak. Si Buyuang Karuik dan Syamsiah. Kehidupan mereka sangat memprihatinkan, keadaan semakin berat bagi kedua anak itu karena tabiat orang tua mereka yang pemarah.

Suatu hari, ketika Syamsiah dan Buyuang Karuik sedang menanak nasi, seekor ayam menghambur masuk dapur menyebabkan periuk di atas tungku terbalik. Melihat itu Buyuang Karuik melempar ayam tersebut, malangnya, ayam kesayangan bapaknya itupun mati. Mereka berdua takut membayangkan amarah bapak dan ibu mereka sehingga memutuskan pergi meninggalkan kampung. 
Mereka menumpang pedati sampai ke kota Padang. Di Padang, Buyuang Karuik membantu mencuci piring sedangkan Samsiah membantu apa yang bisa dibantu di kedai nasi. Kelakuan baik mereka membuat pemilik kedai menyayangi keduanya. Namun Buyuang Karuik sadar mereka tidak mungkin berdua menumpang di sana. Buyuang Karuik meminta pekerjaan di rumah Tuanku Jaksa Lembang Alam. Ia bekerja dengan rajin, gaji yang diterima selalu ditabungnya karena ia ingin berniaga.

Setelah enam bulan, Tuanku Jaksa dipindahkan ke Palembang. Si Buyuang Karuik ikut ke Palembang dan menitipkan Syamsiah pada pemilik kedai. Pemilik kedai itu tidak punya anak dan sudah menganggap syamsiah sebagai anak sendiri. Buyuang Karuik berangkat ke Palembang. Setelah dua tahun di Palembang, Buyuang Karuik meminta izin untuk berniaga dengan tabungannya sebagai modal awal. Tuanku Jaksa mengizinkan dan menambah modal Buyuang Karuik.

Sementara itu, Samsiah dan keluarga angkatnya pindah ke Medan. Di Medan mereka mulai dengan membuka kedai kopi dan goreng pisang serta nasi. Lama kelamaan kedai itu semakin besar dan jaya. Dalam keadaan jaya itu, ayah angkat Syamsiah meninggal dunia. Tidak lama setelah itu, ibu angkatnya menikah lagi dengan laki-laki yang lebih muda. Syamsiah merasa tidak nyaman, beruntung ada orang Belanda membutuhkan babu untuk dibawa ke Betawi. Syamsiah pergi meninggalkan Medan dan merantau ke Betawi.

Akan halnya Buyuang Karuik, perniagaannya semakin sukses. Ia lalu menikah dengan anak saudagar di Palembang dan mendapat gelar Bagindo Karudin. Kehidupan rumah tangganya sangat bahagia, namun sayangnya, istrinya meninggal ketika sedang mengandung sembilan bulan. Bagindo Karudin berduka sangat dalam. Untuk menghibur Karudin, Zainuddin, teman seperniagaannya mengajak Karudin pergi ke Jakarta. Maksud hati akan menumpang di rumah teman Zainuddin, namun sayang, temannya sudah pindah. Untung ada seorang ibu tua bernama Amai Sarijah, menawarkan rumahnya untuk tempat menginap. Amai Sarijah tinggal dengan seorang gadis bernama Siti Sarinam. Singkat cerita, Bagindo Karudin saling jatuh cinta dengan Siti Sarinam, mereka menikah atas izin Amai Sarijah. Seminggu setelah menikah, Karudin mengajak Sarinam dan Amai Sarijah pulang ke Palembang. Di Palembang mereka hidup bahagia dengan kehadiran seorang anak perempuan, perniagaanpun semakin sukses.

Setelah lima belas tahun merantau, Karudin berniat pulang kampung. Mereka pulang sekeluarga termasuk Amai Sarijah. Sesampainya di pelabuhan Padang, Karudin mencari kedai nasi tempat ia menitipkan adiknya dulu. Namun ia hanya mendapatkan kabar adiknya pindah ke Medan dan terakhir pergi ke Betawi. Karudin langsung menuju Pariaman. Ayah dan ibunya sudah tua dan sakit-sakitan. Mereka bertemu dan bertangis-tangisan. Akan halnya Sarinam, sejak sampai di rumah itu, hatinya sangat gelisah. Ia lalu mengakui bahwa dialah Syamsiah yang sudah berganti nama menjadi Sarinam karena kejadian pahit di masa lalu.

Mendengar penuturan istrinya, Karudin terkejut bukan kepalang, dia sama sekali tidak tahu bahwa istrinya adalah adik kandungnya sendiri. Amai Sarijah lalu mengusulkan untuk merahasiakan perkawinan sedarah itu, dan selanjutnya akan dikatakan bahwa suami Syamsiah sudah meninggal makanya Syamsiah dibawa pulang kampung oleh kakaknya. Rahasia itu hanya keluarga yang tahu. 
Karudin mengganti rumah orang tuanya dan membelikan sawah dan ladang untuk orangtuanya. Ia lalu menikah dengan Sakdiah, gadis cantik dari sungai sirah. Setelah menikah mereka kembali ke Palembang. Adapun Syamsiah lalu menikah dengan Saidi Tamam yang menjadi kapala dalam nagari.

\section{Faktor-Faktor Penyebab Terjadinya Perkawinan Sedarah dalam Kaba Si Buyuang Karuik}

Berdasarkan karakteristik kaba, KSBK termasuk kaba modern karena bercerita tentang Si Buyuang Karuik yang awalnya hidup miskin namun akhirnya berhasil dalam perniagaannya. Mengingat kaba adalah cerminan kehidupan sosial masyarakat pemiliknya, KSBK juga mencerminkan kehidupan masyarakat di ranah pariaman yang terjadi pada masa lampau yang dekat, akhir abad ke-19. Kehidupan perekonomian yang sulit pada masa itu menjadi alasan Si Buyuang Karuik pergi merantau dan meninggalkan kampung halaman. Pengalaman kehidupan yang sulit itu pula yang menyemangatinya untuk membangkit batang terendam, bekerja giat demi memeroleh kehidupan perekonomian yang mapan, sehingga bisa duduk sama rendah dan berdiri sama tinggi dengan orang-orang. Pengalaman kehidupan sulit itu pulalah yang menjadi sebab awal terjadinya perkawinan sedarah dalam KSBK.

Kaba tidak hanya berisikan cerita semata, kaba juga berisikan pesan moral. Salah satu pesan moral yang sangat jelas disiratkan dalam KBSK adalah betapapun bahagianya kehidupan rumah tangga, apabila yang dinikahi adalah saudara kandung, rumah tangga itu harus dibinasakan. Berdasarkan pemahaman terhadap isi cerita KSBK, maka ditemukan beberapa faktor yang menyebabkan terjadinya perkawinan sedarah itu. Faktor-faktor penyebab terjadinya perkawinan sedarah dalam KSBK adalah karena 1) Kemiskinan, 2) Kesedihan, 3) Kriminalitas, 4) Cinta, dan 5) Ketidaktahuan.

Berikut paparan masing-masing faktor yang menyebabkan terjadinya Perkawinan Sedarah dalam KSBK.

\section{Kemiskinan}

Apabila dirunut dari awal kisah Si Buyuang Karuik maka akan dipahami bahwa kawin sedarah yang dialami Si Buyuang Karuik, disebabkan karena faktor kemiskinan. KBSK diawali dengan narasi yang menggambarkan kemiskinan keluarganya, seperti terdapat dalam petikan kaba berikut

"Birawari Siti Jamilah, sadang duduak di halaman...susah hati maso itu, hiduik
mularaik bakapanjangan, dapek pagi baa lah patang, dapek patang baa lah pagi,
adang makan adang indak, pikiran kusuik tiok hari, indak ado baati sanang, bakain
lakek di badan, babaju tamba tumamba" (Endah, 1960:11).
'birawari Siti Jamilah, sedang duduk di halaman...susah hati masa itu, hudup
melarat berkepanjangan, dapat pagi bagaimana petang, dapat petang bagaimana
pagi, kadang makan kadang tidak, pikiran kusut setiap hari, tidak penah bersenang
hati, pakaian hanya yang melakat di badan, memakai baju bertambal-tambal'
Dalam petikan kaba itu tergambar kehidupan sulit yang dihadapi keluarga Si Buyuang Karuik. Kemiskinan itu membuat kedua orang tuanya berpikiran kusut setiap hari, sehingga tidak ada kebahagiaan dan kasih sayang yang mereka berikan pada anak-anaknya. Apabila sedikit saja berbuat salah, anak-anak harus 
menanggungkan amarah kedua orangtua mereka. Hal itu seperti dipaparkan dalam petikan kaba berikut

"malang anak nan baduo, tidak bansaik sajo ditangguangkan, tangan jo kaki ditangguangkan pulo, bak karakok tumbuah di batu, hiduik sagan mati tak amuah" (Endah, 1960:12)

'malang kedua anak itu, tidak hanya menanggungkan kemiskinan, tangan dan kaki juga ditanggungkan, bagai kerakap tumbuh di batu, hidup segan mati tak mau'

Kesalahan fatal yang dilakukan Si Buyuang Karuik adalah ketika ia mengusir ayam kesayangan ayahnya dari dapur. Ayam itu terbang menghambur dan menumpahkan nasi yang sedang ditanak. Melihat nasi tertumpah, Si Buyuang Karuik melempar ayam tersebut, tak dikira lemparannya membunuh ayam itu. Ketakutan Si Buyuang karuik dan Si Syamsiah membuat mereka tak berani menghadapi kemarahan orangtuanya. Mereka lalu memutuskan untuk lari meninggalkan kampung halaman. Hal itu seperti yang disebutkan dalam petikan kaba berikut

"Manolah tuan Ajo Karuik, Bapak kito sangaik bangih, kini inyo mancari Ajo, kok dapek dibunuah mati”...mandanga kato nan bak kian, bakato Si Buyuang Karuik "Manolah Kau Upiak Syamsiah, elok pulang Adiak dahulu, denai lari dari siko, mambao untuang kamano pai”, manangih si Syamsiah "Ambo nan usah Ajo tinggakan, kamano Tuan Ambo manuruik, tidak ambo babaliak pulang, baok kamano Tuan pai, satapak tidak Ambo bacarai, matu Tuan mati ambo" (Endah, 1960:14-15).

"Duhai Tuan Ajo Karuik, Bapak kita sangat marah, kini beliau mencari Ajo, jika dapat akan dibunuh mati”... mendengar kata seperti itu, berkata Si Buyuang Karuik "duhai adik Upiak Syamsiah, elok pulang adik dahulu, saya akan lari sini, membawa untung badan', menangis Si Syamsiah, "Saya jangan Ajo tinggalkan, kemana Ajo pergi saya menurut, tidak saya berbalik pulang, bawa kemana Tuan pergi, setapak tidak saya bercerai, mati tuan mati saya".

Berdasarkan pemahaman dari petikan kaba itu dapat disimpulkan bahwa kemiskinan adalah awal mula petaka itu terjadi. Kehidupan yang miskin membuat orang tua Si Buyuang Karuik kehilangan kasih sayang kepada anak-anaknya. Kemiskinan lah pula yang melunturkan kesabaran mereka sehingga begitu mudahnya tersulut emosi. Anak-anak yang masih kecil itu tidak berani menghadapi kemarahan orang tuanya, sehingga memutuskan pergi meninggalkan kampung halaman.

\section{Kesedihan}

Selain karena kemiskinan, perkawinan sedarah dalam KBSK juga disebabkan oleh kesedihan. Kesedihanan dan duka mendalam yang dialami Si Buyuang Karuik menjadi salah satu penyebab terjadinya perkawinan sedarah itu. Seperti dikisahkan dalam kaba, berkat kerja kerasnya, Si Buyuang Karuik sudah menjadi saudagar kaya. Ia menikah dengan Saudah dan bergelar 'Bagindo Karudin'. Kehidupan rumah tangga Bagindo Karudin dan Saudah sangat bahagia, namun sayang tidak berlangsung lama. Saudah meninggal ketika sedang mengandung anak pertama. Hal itu seperti dikisahkan dalam petikan kaba berikut.

"Sampai bilangan sambilan bulan, taraso panek pasandian, lamah sagalo kaki tangan, makan tidak minumpun tidak, muko pucek indak badarah, kan iyo Si Saudah, tidua tilantang tangah rumah, ayia satitak tidak lalu, inyo maliek sajo ka suaminyo, dirangkuahnyo lihia Bagindo Karudin, babisiak maminta maaf "kito bacarai hanyo lai, sampai di siko pambauran, maafkan di Tuan apo nan salah, 
tinggalah Tuan elok-elok, ambo barpulang ke hadirat Allah" kato sampai nyawo barpulang" (Endah, 1960:52)

'Sampai bilangan Sembilan bulan, terasa penat persendian, lemah seluruh kaki dan tangan, makan tidak minumpun tidak, muka pucat tidak berdarah, dan Si Saudah, tidur terlentang di tengah rumah, air setitik tidak lalu, ia hanya melihat pada suaminya, dirangkulnya leher Bagindo Karuddin, berbisik meminta maaf, "kita akan segera bercerai, sampai di sini pembauran, maafkan di Tuan apa yang salah, tinggallah Tuan baik-baik, saya berpulang ke hadirat Allah'

Kehidupan berumah tangga yang baru dijalani Karuddin harus berakhir dengan nestapa. Karuddin yang baru merasakan hidup bahagia harus kehilangan istri dan calon anaknya. Kepergian istri dan anaknya membuatnya nyaris kehilangan akal sehat, seperti yang digambarkan dalam kutipan kaba berikut "Susah hatinyo bagindo Karuddin, inyo duduak bamanuang-manuang surang, tabayang rupo si Saudah, tabayang galak geleng mato, raso mahimbau-himbau juo, tamanuang di batang ayia, maliek biduak hilia mudiak, raso ka disilami sungai Musi, nak samo hilang jo Saudah" (Endah, 1960:55).

'Susah hatinya Bagindo Karuddin, dia duduk bermenung-menung sendiri, terbayang rupa si Saudah, terbayang senyum dan pandangan mata, rasa memanggil-manggil jua, termenung di tepi sungai, melihat biduk hilir mudik, rasa akan diselami sungai Musi, agar sama hilang dengan Saudah'.

Kesedihan Karuddin seakan tak berujung, ia kehilangan semangat hidup. Karuddin menghabiskan hari-hari dengan melamun dan bermuram diri. Melihat itu, Zainuddin, sahabat karibnya, mengajak Karuddin pergi jalan-jalan ke Betawi untuk menghibur diri. Karuddin bersedia pergi dengan harapan hendak menghilangkan kesedihan diri. Hal itu sebagaimana dikisahkan dalam petikan kaba berikut

"Mari kito bajalan, bajalan-jalan ka Batawi, maliek-like koto nan rami", mandanga kato nan bak kian, manjawab Bagindo Karuddin, "Asal rusuah lai tapujuak, kamano sajo kato Zainuddin, ambo nan tidak manupang, hari salasa kapa barangkek, tidak lamo kito di sanan, ganti maliek-maliek nagari urang" (Endah, 1960:57)

'Mari kita berjalan, berjalan-jalan ke Betawi, melihat-lihat kota yang ramai", Mendengar kata itu, menjawab Bagindo Karuddin, "Asalkan rusuh dapat dibujuk, kemana saja kata Zainuddin, Saya yang tidak menentang, hari selasa kapal berangkat, tidak lama kita di sana, ganti melihat-lihat negeri orang'.

Berdasarkan petikan-petikan kaba tersebut dapat disimpulkan bahwa kesedihan yang dialami Karuddin telah menggiring langkahnya ke tanah jawa. Kesedihan dan duka itu mengantarkannya bertemu dengan Siti Sarinam, putri angkat mandeh Sarijah.

\section{Kriminalitas (pelecehan seksual)}

Faktor lain yang menjadi penyebab terjadinya perkawinan sedarah dalam KBSK adalah kriminalitas. Kriminalitas yang dimaksud adalah perbuatan tidak menyenangkan yang mengarah pada pelecehan seksual, dialami oleh Syamsiah. Tindakan tidak menyenangkan itu membuat Syamsiah lari dan ketakutan sehingga harus menyembunyikan identitas aslinya. Karena peristiwa itu Syamsiah harus berganti nama menjadi Siti Sarinam. Peristiwa tidak menyenangkan itu dikisahkan dalam petikan kaba berikut.

"ambo karajo manjadi babu ulando di betawi, tatkalo nyonya ka Banduang, tingga hanyo kami baduo, ambo dipujuak Ulando nantun, disuruah balaku serong, diajak balaku jahek, matonyo dipaliangan setan, hatinyo lah didayo ibilih, lakunyo sarupo musang jantan, dek untuang tolongan Allah, ambo dapek malarikan diri, upeh polisi 
kota Betawi mancari ambo, ambo tukari namo ambo, banamo si Sarinam, kampuang dialiah ka jawa timua, ambo pandai bahaso jawa, surang tidak nan tau, baso ambo urang minang" (Endah, 1960:78-79).

"saya bekerja menjadi pembantu Belanda di Betawi, ketika nyonya ke Bandung, tinggal hanya kami berdua, saya dibujuk Belanda itu, disuruh berbuat serong, diajak berbuat jahat, matanya dipalingkan setan, hatinya telah diperdaya iblis, perilakunya serupa musang jantan, berkat perlindungan Allah, saya berhasil melarikan diri, opas dan polisi kota Betawi mencari saya, saya ganti nama saya, menjadi Si Sarinam, asal saya diganti dari Jawa Timur, karena saya pandai berbahasa jawa, tidak ada seorangpun yang tahu bahwa saya orang Minang".

Pelecehan seksual yang dialami Syamsiah menyebabkan ia harus menyembunyikan identitas aslinya. Sehingga ia dikenal dengan nama Siti Sarinam yang berasal dari Jawa Timur, dan fasih berbahasa Jawa. Penyamaran Syamsiah menjadi Siti Sarinam sangat sempurna, sehingga Si Buyuang Karuik tidak mengenalinya lagi sebagai adik kandung. Berdasarkan hal itu dapat disimpulkan bahwa pelecehan seksual yang dialami Syamsiah adalah salah satu penyebab terjadinya perkawinan sedarah dalam KSBK.

\section{Cinta}

Cinta dapat didefinisikan sebagai perasaan kasih yang mengikat antara lakilaki dan perempuan (KBBI). Perasaan itu timbul karena ada ketertarikan satu sama lain. Dalam KBSK dikisahkan bahwa cinta yang terjalin antara Bagindo Karuddin dengan Siti Sarinam berawal dari pertemuan mereka di rumah Mande Sarijah. Rupa Siti Sarinam yang jelita diam-diam telah menawan hati Bagindo Karuddin. Hal itu seperti yang diceritakan dalam petikan kaba berikut.

"Lorong kapado Bagindo Karuddin, ...takilik iman di dado, maliek rupo Si Sarinam...hati lakek pandanglah sudah, di muko tidak mangasan" (EndAh, 1960:65)

'akan hal Bagindo Karuddin,...tergelitik iman di dada, melihat rupa Si Sarinam, hati lekat pandang lah sudah, namun di muka tidak kelihatan'

Perasaan suka Bagindo Karuddin terhadap Siti Sarinam ternyata tidak bertepuk sebelah tangan. Sarinam diam-diam juga menyimpan perasaan yang sama. Hal itu seperti yang dikisahkan dalam petikan kaba berikut.

"Lorong kapado Bagindo Karuddin jo Si Sarinam, bak antimun jo durian, sarupo api jo rabuak, kanai hati kaduonyo, nan labiah Siti Sarinam, maliek laku elok Karudin, budi baiak parangai elok, pandai batutua sando gurau, tahu kucindan baso basi" (Endah, 1960:66).

'Akan hal Bagindo Karudin dan Si Sarinam, bagai mentimun dan durian, serupa api dengan rabuk, jatuh hati keduanya, terlebih lagi Siti Sarinam, melihat sikap baik Karudin, budi baik perangai baik, pandai bertutur sapa dan bercengkrama, tahu kecindan basa basi'

Berdasarkan kutipan kaba itu dapat dikatakan bahwa antara Bagindo Karuddin dan Siti Sarinam telah sama-sama memendam cinta. Cinta antara seorang laki-laki dan perempuan, bukan cinta kakak kepada adiknya. Perasaan cinta keduanya terang bagai bulan tiga puluh hari, sehingga terbaca jelas oleh Mande Sarijah dan Zainudin. Siti Sarinam telah mengobati kesedihan Bagindo Karudin sehingga mereka memutuskan segera menikah. Setelah menikah mereka kembali ke Palembang membawa serta Mande Sarijah.

\section{Ketidaktahuan}

Meskipun ada faktor kemiskinan, kesedihan, kriminalitas, dan cinta yang melatarbelakangi terjadinya perkawinan sedarah dalam KBSK ini, namun faktor 
yang paling berperan adalah ketidaktahuan. Baik Bagindo Karudin maupun Siti Sarinam sama-sama tidak mengetahui bahwa sebenarnya mereka bersaudara. Begitupun Zainudin dan Mande Sarijah. tidak ada seorangpun yang mengetahui tali darah yang mengikat keduanya. Karena ketidaktahuan itulah makanya perkawinan sedarah itu terjadi.

\section{Akibat Terjadinya Perkawinan Sedarah dalam Kaba Si Buyuang Karuik}

Sebagaimana dikisahkan dalam KSBK, perkawinan Bagindo Karudin dengan Siti Syamsiah dilangsungkan di Betawi, tepatnya di kediaman Mande Sarijah. Pertemuan keduanya terjadi ketika Bagindo Karudin berpelesir ke Betawi untuk menghibur diri setelah kematian istrinya. Tidak ada seorangpun yang tahu bahwa ternyata Bagindo Karudin adalah kakak kandung Siti Sarinam. Perkawinan mereka berawal dari rasa saling membutuhkan satu sama lain. Mereka bahkan berhasil membina rumah tangga yang bahagia selama bertahun-tahun, sampai memiliki seorang putri. Tidak hanya itu, mereka juga sukses dalam perniagaan, seperti yang disebutkan dalam petikan kaba berikut

"Kan iyo Bagindo Karudin, dek elok pambauran, rasaki batambah-tambah, kadaian ketek manjadi gadang, lah musahua kayo Bagindo, dek untuang elok maso itu, dapeklah anak parampuan, buliah pamenan bapak jo mande"(Endah, 1960:67)

'Akan hal Bagindo Karudin, karena baik pembauran, reski bertambah-tambah, toko kecil menjadi besar, termasyur kaya Bagindo, karena nasib baik, dapatlah anak perempuan, sebagai hiburan bagi ayah dan ibu'

Berdasarkan petikan kaba itu dapat disimpulkan bahwa perkawinan antara kedua saudara kandung itu sangat bahagia. Namun kebahagiaan itu serta merta hancur ketika mereka mengetahui pertalian darah antara keduanya. Akibat perkawinan sedarah yang tanpa sengaja mereka lakukan, mereka harus menanggungkan rasa malu, tertekan oleh kesedihan, dan harus menghadapi perceraian. Berikut paparan akibat perkawinan sedarah dalam KSBK tersebut. Malu

Menurut Kamus Besar Bahasa Indonesia, malu adalah merasa sangat tidak enak hati (hina, rendah, dan sebagainya) karena berbuat sesuatu yang kurang baik (kurang benar, berbeda dengan kebiasaan, mempunyai cacat atau kekurangan, dan sebagainya). Mencermati definisi itu, maka demikianlah gambaran yang dirasakan Bagindo Karudin dan Siti Sarinam setelah mengetahui kenyataan bahwa mereka bersaudara. Tidak hanya Karudin dan Sarinam, kedua orang tua mereka pun merasakan malu yang tak terhingga, mendapati kenyataan sepasang anak mereka ternyata kawin sedarah. Hal itu seperti yang dikisahkan dalam petikan kaba berikut.

"Mandanga curito Siti Syamsiah, tapacak paluah gadang Bagindo Karudin, mandingin badan maramang kuduak, ruponyo si Sarinam adiak kanduang balahan diri, ruponyo takawini di adiak kanduang, kok tau urang kampuang, bahaso babini jo adiak kanduang, tantu ka mandapek gala baru, badan bagala Bagindo rutiang...tidak malu samalu nangko, malu tacoreang di kaniang” (Endah, 1960:79). 'mendengar cerita Siti Syamsiah, keluarlah keringat Bagindo Karudin, badan jadi panas dingin, rupanya Sarinam adik kandung belahan diri, rupanya terkawini adik kandung, andai tahu orang kamung, bahwa menikah dengan adik sendiri, tentu akan mendapat gelar baru, badan bergelar Bagindo ruting...tidak malu semalu ini, malu tercoreng di kening'. 


\section{Sedih}

Rumah tangga bahagia yang telah dibina oleh Bagindo Karudin dengan Si Sarinam harus diakhiri. Kenyataan bahwa mereka bersaudara tidak hanya menimbulkan rasa malu dan terkejut, namun juga sedih dan sesal. Sarinam yang menyadari pertalian itu dikisahkan jatuh pingsan karena tidak sanggup menahan kesedihan hati, sebagaimana yang disebutkan dalam petikan kaba berikut,

"kununlah si Sarinam, sajak tibo di rumah nantun, hati nan indak sanang lai, dirameh paruik dikaluahkan, mandanga kato bapak kanduang, manangih si Sarinam, manangih manggaruang panjang, manggigia manahan hati,..., kato sampai inyopun pangsan, tidak tahu di dirinyo, karano manahan hati" (Endah, 1960:78-79).

'akan hal Si Sarinam, sejak tiba di rumah itu, hati yang tidak senang lagi, diremas perut dkeluhkan, mendengar kata bapak kandung, menangis Si Sarinam, menangis menjerit panjang, menggigil menahan hati,..., kata sampai dia pun pingsan, tidak tahu akan dirinya, karena menahan hati'.

\section{Perceraian}

Meskipun perkawinan Bagindo Karudin dengan Siti Sarinam terjadi karena ketidaktahuan mereka. Namun perkawinan itu adalah perkawinan terlarang. Terlarang dari sudut pandang agama dan adat. Sehingga perkawinan tersebut harus berakhir dengan perceraian. Tidak hanya menuntut perpisahan, perceraian itu juga menuntut kesepakatan seluruh keluarga untuk merahasiakan perkawinan sedarah yang terlanjur terjadi itu. Hal itu seperti dikisahkan dalam petikan kaba berikut

"Manolah kito samuonyo, sabalun urang balun tahu, balun tabatiak tabarito, urang nan lain tidak mandanga, elok dibuhua dalam hati, katokan Syamsiah kamatian laki, dibaok pulang dek tuannyo, usah dikatoan laki bini, malu kita di urang banyak" (Endah, 1960:80).

"manalah kita semua, sebelum orang tahu, belum terbetik terberita, orang yang lain tidak mendengar, baik dibuhul dalam hati, katakana Syamsiah kematian suami, dibawa pulang oleh kakaknya, usah dikatakan suami istri, malu kita di orang banyak'.

Demikianlah dampak perkawinan sedarah dalam KSBK. Perkawinan itu dikatakan terlarang karena terjadi antara kakak dan adik kandung. Meskipun disebabkan oleh takdir yang berliku, namun ia telah mendatangkan rasa malu yang menekan, kesedihan yang tak terperi, dan meminta perceraian yang memilukan.

\section{PENUTUP}

KSBK adalah salah satu karya sastra milik masyarakat nagari Pariaman karena cerita kaba berlatarkan nagari Pariaman dan bercerita tentang kehidupan masyarakat Pariaman. KSBK termasuk kaba modern yang berkisah tentang seorang anak muda yang di awal cerita hidup miskin namun karena usahanya ia berhasil membangkit batang terendam. Sebagaimana kaba lainnya, KSBK juga mengandung pesan moral yang dapat dijadikan tuntunan oleh masyarakat. Salah satu pesan moral yang paling kentara adalah 'meskipun memiliki rumah tangga yang bahagia, namun bila menikahi saudara sendiri, maka rumah tangga itu harus diakhiri.

Berdasarkan pembacaan yang cermat terhadap isi KSBK diperoleh kesimpulan bahwa perkawinan sedarah dalam KSBK terjadi karena lima faktor, 
Tuah Talino

Tahun XIII Volume 13 Nomor 2 Edisi 6 Desember 2019

ISSN 0216-079X E-ISSN 2685-3043

Balai Bahasa Kalimantan Barat

yakni faktor kemiskinan, kesedihan, kriminalitas, cinta, dan faktor ketidaktahuan. Sedangkan perkawinan sedarah yang terlanjur terjadi itu telah menyebabkan rasa malu yang tak terhindarkan, rasa sedih yang tak tertanggungkan, dan menagih perceraian yang tak terhindarkan.

\section{DAFTAR PUSTAKA}

Abdullah, Taufik. (2009). "Beberapa Catatan Tentang Kaba Cindua Mato:Satu Contoh Sastera Tradisional Minangkabau", dalam Jurnal Terjemahan Alam dan Tamadun Melayu, 1.

Arikunto S. (1998). Prosedur Penelitian Suatu Pendekatan Praktek. Cetakan ke11. Jakarta: PT Rineka Cipta.

Bogdan, Robert dan Steven Taylor. (1992). Pengantar Metode Kualitatif. Surabaya: Usaha Nasional. Basari.

Damono, Sapardi Djoko. (1978). Sosiologi Sastra Sebuah Pengantar. Jakarta: Pusat Pembinaan dan Pengembangan Bahasa.

Djais, Mochammad. (2006). Hukum Harta Kekayaan Dalam Perkawinan. Semarang: Fakultas Hukum Universitas.

Djamaris, Edwar. (2004). Kaba Minangkabau. Jakarta: Pusat Bahasa.

Endah, Syamsuddin St. Radjo.(1960).Kaba Si Buyuang Karuik.Bukittinggi:Kristal Media.

http://sosiologis.com/sosiologi-sastra diunduh tanggal 13 Agustus 2019.

http://erialfiansyah94.blogspot.com/2015/04/kebudayaan-perkawinanminangkabau.html. diunduh tanggal 13 Agustus 2019.

https://www.liputan6.com/news/read/4003940/yang-terkuak-dari-kasusperkawinan-sedarah-di-bulukumba. diunduh tanggal 13 Agustus 2019.

https://www.tribunnews.com/regional/2019/07/28/cinta-terlarang-kakak-adik-diluwu-. diunduh tanggal 13 Agustus 2019.

https://dalamislam.com/hukum-islam/pernikahan/syarat-pernikahan-dalam-islam. diunduh tanggal 13 Agustus 2019.

Ibrahim, Abdul Syukur.(2009). Metode Analisis Teks dan Wacana.Yogyakarta: Pustaka Pelajar.

Karini, Ajeng Desi.(2007). "Perkawinan Campur dalam Novel Rojak Karya Fira Basuki".tesis.

Pradopo, Rachmat Djoko.(1995). Beberapa Teori Sastra, Metode Kritik, dan Penerepannya. Yogyakarta: Pustaka Pelajar.

Saputra, Anggha Triyoga.(2018). "Perkawinan daam Novel Ketika Cinta Bertasbih Perspektif Hukum Perkawinan Islam di Indonesia".Tesis.

Soemiyati.(1986). Hukum Perkawinan Islam dan Undang-Undang Perkawinan. Yogyakarta Liberty.

Sudaryanto.(2015). Metode dan Aneka Teknik Analisis Bahasa. Yogyakarta: Sanata Dharma University Press. 